\title{
Economic Policy Uncertainty and Corporate Leverage Ratio: Evidence in China
}

\author{
Yuxin Huang ${ }^{1 *}$ \\ ${ }^{1}$ School of Business, Massey University, Auckland, 0745, New Zealand \\ *Corresponding author. Email: guanghua.ren@gecacademy.cn
}

\begin{abstract}
In the context of the current unstable macroeconomic environment, we explored the impact of economic policy uncertainty on the corporate leverage ratio. The study found that economic policy uncertainty significantly reduces firm leverage ratios. This relationship holds significantly after a series of robustness tests, supporting the point of risk aversion among corporate executives. Meanwhile, we found that firms are more inclined to reduce their short-term debt levels since short-term debts induce a greater liquidity risk for firms. Furthermore, we found that economic policy uncertainty affects firms' behavior of reducing their leverage ratio mainly in non-state-owned enterprises and firms not audited by the Big Four auditors. This paper has a certain reference significance for the enterprise's riskrelated decision-making under the current macroeconomic environment.
\end{abstract}

Keywords: Economic policy uncertainty, leverage, debt ratio.

\section{INTRODUCTION}

Corporate leverage is a measure created for quantifying the number of debts implied compared to the number of assets the companies have. It is defined as the ratio of outstanding Total Liabilities divided by the Total Assets. This figure is widely considered an important index to firms' maintenance and development since it is linked to all areas, including market risk, financial performance, and profitability. Theoretically, companies can benefit from using the debt since payments of interest are tax-deductible, and by doing this, they may increase the firm value. However, it is not always applicable for a company to increase debt, especially for those with excessive debt ratios. This is because high indebtedness may lead to significant financial limitations and negatively influence firm performance [1].

Among them, corporate leverage is deemed most directly related to risk. Gahlon [2] showed that, in general, a systematic corporate risk should increase with increases in its degree of operating leverage. Lev [3] also provided empirical evidence of a positive correlation between operating leverage and market risk based on Rubinstein's analysis model.

Many may think that corporate leverage is solely determined by the internal factors of the companies while ignoring the impact from the external environment. Previous pieces of literature conclude that companies' size, growth, profitability, liquidity, and tangibility are all obvious factors affecting companies' leverage ratios.

Although the corporate leverage ratio is imposed by corporate themselves, often, it is largely influenced by factors outside the company. For example, Barclay et al. [4] concluded that taxes, contracting costs, and signaling effects influence corporate leverage factors after analyzing the leverage history of 6,700 industrial companies over 30 years. The leverage cycle theory raised by a few researchers also provided sideways proofs. Geanakoplos [5], who introduced the concept of the leverage cycle, mentioned that leverage becomes too high in economic boom times and too low in recession times with the absence of intervention, provided the fact that leverage dramatically increased in the United States and globally from 1999 to 2006. Geanakoplos also mentioned a central bank could smooth economic activity by curtailing leverage in normal or ebullient times and propping up leverage in anxious times. In his words, central banks can monitor and regulate leverage and interest rates. Because of the cyclical nature of national economies, the leverage ratio of companies will inevitably change together. 
Changes in economic policies can essentially explain the impact on companies' leverage caused by cyclical economies. This paper explored the impact of economic policy uncertainty on corporate leverage ratio and found that economic policy uncertainty can significantly reduce the leverage ratio of companies. This relationship still significantly holds after a series of robustness tests, including changing the measurement index and adding missed variables. Meanwhile, we found that firms are more inclined to reduce their shortterm debt levels since short-term debts induce a greater liquidity risk for firms. Furthermore, we found that economic policy uncertainty affects firms' behavior of reducing their leverage ratio mainly in non-state-owned enterprises and firms not audited by the Big Four auditors.

\subsection{Design of the study}

Our research samples were selected from all listed companies on the Shanghai and Shenzhen stock exchanges from 2007 to 2018. We focus on China's Ashare market for the following reasons. Firstly, China is a developing country with many differences in the choice of capital structure compared to developed countries. Developing country firms often face constraints in financing choices available to them, and most importantly, they relate to government controls [6]. Since there are excessive government policy changes, especially when China is a rapidly growing economy, firms may tend to be more rational and conservative with capital costs and financial structures.

Secondly, the A-share market only consists of common stocks issued by companies in China for domestic institutions, organizations, or individuals (excluding investors from Taiwan, Hong Kong, and Macao) to subscribe and trade in RMB. It excludes Bshare, $\mathrm{H}$-share, and $\mathrm{N}$-share, which have foreign elements in the currency of trade, place of listing, and trading. This exclusion is because other stocks have a high probability of foreign investors, which would cause inaccuracy from information asymmetry [7].

\subsection{Contributions of the paper}

The contributions of this paper are as follows. Firstly, to the best of our knowledge, this study extended the impact of policy uncertainty on the overall economy by accentuating its effect on corporate leverage. Identifying the direction and degree of influence of EPU on firms is essential, especially for developing countries such as China. Rodrik [8] discovered that reform taking place in developing countries could lead to delayed private investment until the uncertainty is eliminated.

Secondly, this study notes that variations in property rights attributes and audit quality are possible factors that will influence the effect of EPU on leverage. Whether the firm is non-state-owned or state-owned, whether the Big Four auditors audit it will all differ in the firm reacting to economic policy uncertainties.

Moreover, this paper discovers that firms are more inclined to reduce their short-term debt levels when uncertainty arises since short-term debts induce a greater liquidity risk. This result followed that suggestion given by Dadush, Dasgupta, and Ratha [9], who stated that it is essential for firms in developing countries to monitor short-term debt closely and manage them effectively to avoid currency and liquidity crises since excessive amounts of short-term debts will pose a high risk for developing countries.

Finally, this paper has a certain reference significance for the enterprise's risk-related decisionmaking under the current macroeconomic environment.

\subsection{Paper Structure}

The remainder of this study is organized as follows. Section 2 includes a review of the literature and the development of our hypothesis. Section 3 describes the research design, including sample selection, model specification, and variable measurement. Section 4 listed the empirical results, provides robustness checks and performs further analyses, including the moderating effects of the monitoring mechanisms and an alternative explanation of the eyeball effect. Section 5 concludes the paper.

\section{LITERATURE and HYPOTHESIS}

\subsection{Literature Review}

The validity of the measuring index called EPU has been tested positive in several different approaches by its founder, Baker [10]. For instance, they are relating EPU to other measures of economic uncertainty, such as stock market volatility, which showed a strong relationship. There is also a strong relationship between EPU and other measures of policy uncertainty, for example, the frequency with which the Federal Reserve System's Beige Books mention policy uncertainty. In addition, political slant does not seriously distort the overall EPU index as researchers found very similar movements in EPU indexes based on newspapers of different political stances.

The practical test researchers let trained teams of University of Chicago students read overlapping sets of randomly selected articles from U.S. newspapers and assess whether each of them discusses economic policy uncertainty. All students were guided by a 65-page reference manual and weekly team meetings. The results showed a high correlation between human- and computer-generated indexes ( 0.86 in quarterly data from 
1985 to 2012 and 0.93 in annual data from 1900 to 2010), with the discrepancy between the human and computer-generated indexes uncorrelated with GDP growth rates and level of EPU.

Finally, EPU indexes were validated to have a market used by commercial data providers, including Bloomberg, FRED, Haver, and Reuters, which carry them to meet demands from banks, hedge funds, corporations, and policymakers. All evidence shows that EPU is a reliable and useful measure of economic policy uncertainty.

\subsection{Hypothesis Development}

Our analysis is motivated by multiple papers that illustrate the impact of EPU on corporate leverage. Among them, the generally believed rule is that firms tend to lower their leverage ratios when a degree of economic policy uncertainty increases [11]. It is supported by empirical evidence and statistical data from various researchers.

Trung [12] found that economic policy uncertainty negatively affects corporate risk-taking by setting up a model analyzing a sample of 151,483 observations from 16,274 unique firms across 18 countries during the period from 2005 to 2016. The BBD index he used measures economic policy uncertainty based on Baker, Bloom, and Davis's (2016) news-based index and carries out the same role as the EPU index in another research.

Apart from this general rule, some have found that the influence of EPU on leverage has its degree differs between countries. Qiu and Li's [13] research exemplified this finding. They studied two large panel datasets of 5,360 US firms and 717 German firms from 1985 to 2015 and 1993 to 2015 , trying to identify the link between financial leverage ratios and EPU News Index in tranquil and crisis periods. The result showed that there is a positive correlation between higher EPU and lower leverage. However, US firms become more cautious levering up when policy uncertainty is high during crisis periods but not tranquil periods. While German firms respond negatively to an increase in the EPU news index in tranquil and crisis periods. This finding insinuates that German firms tend to borrow less in general when policy uncertainty is high, which is different from the US.

In Makololo and Seetharam's [14] research focusing on EPU's effect on leverage in BRICS countries, they found that EPU is significant in determining leverage financing decisions in Russian, Indian, and South African companies, after analyzing the top 80 listed firms in each respective country from the beginning of June 2002 to the end of June 2017. However, contrary results in Brazilian and Chinese firms appeared, which is not anticipated. The authors suggested that firms in these countries are more prone to react when there is uncertainty since they can take the opportunity of cheaper debt when there is uncertainty in the market. This unanticipated finding intrigued us to use larger and more comprehensive data to continue the research in China. Since Makololo and Seetharam's research only analyzed the data of the Top 80 companies of each country, which was not fully representative in general, he did not concentrate on analyzing the impact of EPU in the Chinese market. We believe that the study of larger data, such as the data of more than 4,000 listed companies in this paper, will be more representative of China.

Based on this, when designing the study for the Chinese economy, we propose the following hypothes:

H1a: Economic policy uncertainty will significantly increase the leverage ratio of companies, the other thing being equal.

$\boldsymbol{H} 1 \boldsymbol{b}$ : Economic policy uncertainty will significantly decrease corporate leverage, other things being equal.

\section{RESEARCH DESIGN}

\subsection{Construction of Sample}

Our research samples were selected from all listed companies on the Shanghai and Shenzhen stock exchanges from 2007 to 2018. All financial data are retrieved from the CSMAR (China Stock Market \& Accounting Research Database). This is an accurate research-type database in the field of economics and finance developed by Shenzhen CSMAR Data Technology Co., Ltd., referenced to CRSP, CompStat, TAQ, THOMSON, and other authoritative database professional standards and based on the needs of academic research. CSMAR is used by multiple universities as a reference to write papers and is considered to contain authoritative data.

At the same time, to ensure the robustness of the results and avoid the impact of other sample errors, data of firms in the financial industry and ST shares were excluded from our sample. Further, we perform a $1 \%$ level of indentation for all continuous variables.

\subsection{Models}

The hypotheses to be stated are the firm's leverage in the year $t+1$ is a function of EPU and other control variables. The basic empirical model employed is:

$L e v_{t+1}=\beta_{0}+E P U_{t}$

\section{$+\Sigma \beta_{q}($ qth ControlVariablet $)+\varepsilon$}

where $\beta_{0}$ represents regression coefficients; ControlVariable contains Size, Frst, Age $e_{t}$, Growth $_{t}$, 
CrossList $t_{t,}$ and $G D P_{t .} \varepsilon$ is an error term; $L e v_{t+1}$ is the leverage ratio of firms at year $(\mathrm{t}+1) ; E P U_{t}$ is the EPU ratio in year $\mathrm{t}$.

\subsection{Variables}

\subsubsection{Dependent variable: Lev $_{t+1}$}

We choose the ratio of total liabilities to total assets as the index of corporate leverage ratio being studied. Meanwhile, we use the ratio of short-term debt to total assets (denoted SLev) to measure the company's shortterm leverage and use the ratio of long-term debt to total assets (denoted LLev) to measure the company's longterm leverage. The reason for differentiating short-term leverage and long-term leverage is that they have different effects on the volatility of the stock, which is proved closely related to the company's operating performance.

"The short-term leverage effect contributes more heavily than the long-term leverage effect in forecasting the stock return performance.", stated by Pan and Liu [15] after investigations on stock return volatility using the GARCH-MIDAS model [16] decomposes the volatility into short-term and long-term volatility component. While stock return volatility and performance have explanatory linkage to operating performance to some degree, shown by Dehuan and Jin [17]. In general, this implies that short-term debts and long-term debts have different effects, hence are treated differently in companies. To prove this, in addition to analyzing the impact on leverage, we distinguish between long-term leverage and short-term leverage and analyze them separately.

\subsubsection{Test variable: $E P U_{t}$}

The methodology used when establishing the measurement of economic policy uncertainty used in this paper - the EPU index is measuring the frequency of articles in 10 leading U.S. newspapers that contain the terms implying economic uncertainties, including "economy," "uncertain," "Congress," "deficit," "Federal Reserve," and "legislation". This index was developed by Scott R. Baler, Nick Bloom, and Steven J. Davis [9], and its reliability is explained in Section 2.1.

\subsubsection{Control variables: Size $_{t}$, Frs $_{t}$, Age $_{t}$, Growth $_{t}$, CrossList $t_{t}$, and GDP ${ }_{t}$}

The above indices, as factors determining leverage, would distort our study of how EPU affects leverage. Alkhatib's [18] findings are consistent with the point that the above factors will affect leverage ratios in most cases. He confirms that firm and economic variables are related and impact leverage after investigating 121 listed companies on the Jordanian Stock Exchange. He listed some factors, for instance, the size of the firms, which is a very important factor since larger firms have a favorable position over smaller firms in terms of credit ratings. He also proved that a rise in the growth rate of a firm should indicate higher demands for funds from external sources, including debts, therefore influence the leverage. Also, Mirza, Rehman, and Zhang [19] analyzed firm and country-level determinants of leverage in Chinese firms and found profitability, firms' growth potential. GDP has a significant influence on firms' leverage. They implied that firms having profitability and greater tangibility tend to raise less debt and have lower leverage. Real growth in GDP was found to have a negative relationship with leverage.

Cross-listing offers a company advantages on financing, including access to less expensive capital, diversification of risk, future growth opportunities, and financial flexibility [20]. Dynamics between a firm's credit and equity returns change after foreign listings [21]; And as listing age increases, the possibility of seeking higher financing decreases. In this way, whether a firm is cross-listed and its listing age on other stock exchanges should be a control variable.

\section{EMPIRICAL ANALYSIS}

\subsection{Descriptive Analysis}

Table 1 provides descriptive statistics for the variables used in the analysis. The leverage measures, $L e v_{t+1}$, have a mean of 0.476 , a maximum of 0.988 , and a minimum of 0.060 . The spread between maximum and minimum and the standard deviation of 0.207 combinedly reflect the debt ratio of various companies varies greatly and is commonly high.

The measurement of economic policy uncertainty, $E P U_{t}$, has a maximum of 6.132 and a minimum of 4.410 .

By looking at differences between $S L e v_{t+1}$ and LLev $v_{t+1}$, we discovered similar standard deviations of 0.109 and 0.104 and different means of 0.112 and 0.082 , respectively. This indicates Chinese firms commonly have short-term debt greater than long-term debt. However, the future risks of short-term debt are more unstable and will make future investment incentives unstable and affect current investment incentives. Diamond and $\mathrm{He}$ [22] asserted that short-term debt generally poses a lower threat; Long-term debt matters less if assets are more volatile in a bad economy. For future investments, the reduced correlation between asset availability and investment opportunities increases the short-term debt burden. This is consistent with the situation we analyze in our study, in which firms are experiencing high levels of economic policy uncertainties and their short-term debt burden increases more. 
Table 1. Descriptive Statistics. This table reports descriptive statistics on leverage, EPU, and control variables of the sample in 2007-2018. All variables are defined in Appendix. A.

\begin{tabular}{|c|c|c|c|c|c|c|}
\hline variable & $\mathrm{N}$ & mean & $\mathrm{sd}$ & $\min$ & p50 & $\max$ \\
\hline$L e v_{t+1}$ & 21749 & 0.476 & 0.207 & 0.060 & 0.479 & 0.988 \\
\hline SLev $_{t+1}$ & 21749 & 0.112 & 0.109 & 0 & 0.085 & 0.482 \\
\hline LLev $_{t+1}$ & 21749 & 0.082 & 0.104 & 0 & 0.039 & 0.464 \\
\hline$E P U_{t}$ & 21749 & 5.221 & 0.522 & 4.410 & 5.188 & 6.132 \\
\hline $\operatorname{Lev}_{t}$ & 21749 & 0.469 & 0.212 & 0.053 & 0.472 & 1.008 \\
\hline Size $_{t}$ & 21749 & 21.97 & 1.332 & 19.30 & 21.79 & 26.000 \\
\hline $\mathrm{Age}_{t}$ & 21749 & 2.738 & 0.366 & 1.609 & 2.773 & 3.401 \\
\hline Frst & 21749 & 0.356 & 0.151 & 0.089 & 0.337 & 0.750 \\
\hline Growth $_{t}$ & 21749 & 0.223 & 0.566 & -0.597 & 0.124 & 4.095 \\
\hline CrossList $t_{t}$ & 21749 & 0.069 & 0.254 & 0 & 0 & 1 \\
\hline$G D P_{t}$ & 21749 & 0.121 & 0.047 & 0.070 & 0.104 & 0.231 \\
\hline
\end{tabular}

\subsection{Variables}

There are 11 variables included in this study as shown in Table 2.

Table 2. Variables

\begin{tabular}{|c|c|}
\hline Levt+1 & $\begin{array}{l}\text { The asset-liability ratio of the company I at } \\
\text { period } t+1\end{array}$ \\
\hline SLevt $t+1$ & $\begin{array}{l}\text { The short-term asset-liability ratio of the } \\
\text { company I at period } t+1\end{array}$ \\
\hline LLev $_{t+1}$ & $\begin{array}{l}\text { The short-term asset-liability ratio of the } \\
\text { company I at period } t+1\end{array}$ \\
\hline$E P U_{t}$ & $\begin{array}{l}\text { Economic Policy Uncertainty Index (annual } \\
\text { mean of monthly data) }\end{array}$ \\
\hline $\operatorname{Lev}_{t}$ & $\begin{array}{l}\text { The debt-to-asset ratio of the company I at } \\
\text { period } t\end{array}$ \\
\hline Size $_{t}$ & $\begin{array}{l}\text { The total market value of company I at } \\
\text { period } t\end{array}$ \\
\hline $\mathrm{Age}_{t}$ & The listing age of company I in period $t$ \\
\hline$F r s t$ & $\begin{array}{l}\text { The proportion of company I's fixed assets } \\
\text { in period } t\end{array}$ \\
\hline Growth $_{t}$ & $\begin{array}{l}\text { The growth rate of the gross domestic } \\
\text { product in period } t\end{array}$ \\
\hline CrossList & $\begin{array}{l}\text { Whether Company I is cross-listed in Phase } \\
\mathrm{T} \text { (A-shares - Hong Kong shares }\end{array}$ \\
\hline$G D P_{t}$ & The growth rate of the gross domestic \\
\hline
\end{tabular}

product in period $\mathrm{t}$

Appendix. A. The abbreviations and meanings of variables.

\subsection{Multivariate Results}

Fundamental regression result shows that EPU's influence on leverage is significantly negative at the $5 \%$ level before adding control variables. After adding control variables, the result is still negative $(-2.53$ on the 4th column). This insinuates a relationship that links firms decreasing their leverage and rising EPU.

Moreover, after differentiating long-term leverage and short-term leverage, we found that the estimation of the impact of EPU on short-term leverage is -9.10, which shows a higher effect than on long-term leverage $(-6.22)$. This rule is also confirmed when the control variables are not added because the absolute value of the EPU's impact on short-term leverage without the control variables $(-2.26)$ is affected more than that of the long-term leverage under the same context (-1.84). 
Table 3. Multivariate statistics. Column (1) (2) \& (3) shows results without control variables. Column (4) (5) \& (6) shows results after adding control variables.

\begin{tabular}{|c|c|c|c|c|c|c|}
\hline & (1) & (2) & (3) & (4) & (5) & (6) \\
\hline & F_Lev & F_sLev & F_lLev & F_Lev & F_sLev & F_lLev \\
\hline \multirow[t]{2}{*}{ EPU } & $-0.009 * *$ & $-0.021 * * *$ & $-0.011 * * *$ & $-0.080 * * *$ & $-0.035 * *$ & $-0.028 *$ \\
\hline & $(-2.53)$ & $(-9.10)$ & $(-6.22)$ & $(-3.47)$ & $(-2.26)$ & $(-1.84)$ \\
\hline \multirow[t]{2}{*}{ Lev } & & & & $0.860 * * *$ & $0.272 * * *$ & $0.128 * * *$ \\
\hline & & & & (187.92) & (31.97) & (18.99) \\
\hline \multirow[t]{2}{*}{ Size } & & & & $0.006 * * *$ & $-0.007 * * *$ & $0.019 * * *$ \\
\hline & & & & $(8.87)$ & $(-4.74)$ & (14.41) \\
\hline \multirow[t]{2}{*}{ Age } & & & & $-0.009 * * *$ & $-0.008^{*}$ & $-0.006^{*}$ \\
\hline & & & & $(-5.06)$ & $(-1.81)$ & $(-1.73)$ \\
\hline \multirow[t]{2}{*}{ Frs } & & & & -0.004 & $-0.019 * *$ & $-0.021 * *$ \\
\hline & & & & $(-0.98)$ & $(-2.01)$ & $(-2.40)$ \\
\hline \multirow[t]{2}{*}{ Growth } & & & & 0.000 & $-0.005 * * *$ & $0.003 * *$ \\
\hline & & & & $(0.23)$ & $(-3.75)$ & $(2.52)$ \\
\hline \multirow[t]{2}{*}{ CrossList } & & & & -0.003 & $-0.023^{* * *}$ & -0.006 \\
\hline & & & & $(-1.09)$ & $(-3.21)$ & $(-0.92)$ \\
\hline \multirow[t]{2}{*}{ GDP } & & & & $-1.103 * * *$ & -0.324 & $-0.388^{*}$ \\
\hline & & & & $(-3.55)$ & $(-1.51)$ & $(-1.86)$ \\
\hline \multirow[t]{2}{*}{ _cons } & $0.521 * * *$ & $0.299 * * *$ & 0.001 & $0.576^{* * *}$ & $0.475 * * *$ & -0.175 \\
\hline & (17.13) & (15.14) & $(0.10)$ & (3.32) & $(3.84)$ & $(-1.46)$ \\
\hline $\mathrm{N}$ & 21749 & 21749 & 21749 & 21749 & 21749 & 21749 \\
\hline $\begin{array}{l}\text { Industry } \\
\text { Fixed effect }\end{array}$ & Yes & Yes & Yes & Yes & Yes & Yes \\
\hline $\begin{array}{l}\text { Year Fixed } \\
\text { Effect }\end{array}$ & Yes & Yes & Yes & Yes & Yes & Yes \\
\hline r2_a & 0.148 & 0.072 & 0.238 & 0.825 & 0.286 & 0.376 \\
\hline
\end{tabular}

t statistics in parentheses

$* \mathrm{p}<0.1, * * \mathrm{p}<0.05, * * * \mathrm{p}<0.01$

\subsection{Robustness tests}

To prove the robustness of the estimated results, we conducted the following robustness test. In the first column, the second column, and the third column, we used the measurement index of EPU developed by David [23], which is different from the EPU measurement index developed by Baker [10]. We use the measurement index invented by David as an alternative indicator to prove the authenticity and robustness of our findings.
After we replace the EPU index, we find that the estimated index of the impact of EPU in the first column on leverage at the level of $1 \%$ is -0.049 and significantly negative, which is consistent with our findings. Meanwhile, results in the second and third columns still prove a higher impact of EPU on short-term leverage (0.022), which shows a higher effect than long-term leverage (-0.017).

We added these variables to the robustness test to avoid some variables that may not have been considered causing endogeneity problems to the estimated results 
and findings above. These added variables include whether it is a state-owned enterprise, whether it is audited by the Big Four audit firms, gender of the company's senior executives, age of the senior executives, and duality of senior executives. By analyzing the new results, we find that the data on the fourth column is still significantly negative, indicating that the impact of EPU on leverage is authentic and robust. In the fifth and sixth columns, data are -0.035 and -0.028 for EPU's impact on short-term leverage and long-term leverage, respectively, indicating that EPU's impact on short-term leverage is still greater than the impact on the long-term leverage.

Table 4. Robustness tests.

\begin{tabular}{|c|c|c|c|c|c|c|}
\hline & (1) & (2) & (3) & (4) & (5) & (6) \\
\hline & F_Lev & F_sLev & F_ILev & F_Lev & F_sLev & F_ILev \\
\hline \multirow[t]{2}{*}{ EPU_d } & $-0.049 * * *$ & $-0.022 * *$ & $-0.017 *$ & $-0.083 * * *$ & $-0.035^{* *}$ & $-0.028^{*}$ \\
\hline & $(-3.47)$ & $(-2.26)$ & $(-1.84)$ & $(-3.60)$ & $(-2.26)$ & $(-1.86)$ \\
\hline \multirow[t]{2}{*}{ Lev } & $0.860 * * *$ & $0.272 * * *$ & $0.128 * * *$ & $0.860 * * *$ & $0.274 * * *$ & $0.128 * * *$ \\
\hline & (187.92) & (31.97) & (18.99) & (186.59) & (32.23) & (19.13) \\
\hline \multirow[t]{2}{*}{ Size } & $0.006 * * *$ & $-0.007 * * *$ & $0.019 * * *$ & $0.006 * * *$ & $-0.005 * * *$ & $0.020 * * *$ \\
\hline & $(8.87)$ & $(-4.74)$ & (14.41) & (9.13) & $(-2.97)$ & (15.02) \\
\hline \multirow[t]{2}{*}{ Age } & $-0.009 * * *$ & $-0.008^{*}$ & $-0.006^{*}$ & $-0.009 * * *$ & -0.005 & -0.005 \\
\hline & $(-5.06)$ & $(-1.81)$ & $(-1.73)$ & $(-4.83)$ & $(-1.11)$ & $(-1.34)$ \\
\hline \multirow[t]{2}{*}{ Frs } & -0.004 & $-0.019 * *$ & $-0.021 * *$ & -0.003 & -0.011 & $-0.018 * *$ \\
\hline & $(-0.98)$ & $(-2.01)$ & $(-2.40)$ & $(-0.74)$ & $(-1.15)$ & $(-1.99)$ \\
\hline \multirow[t]{2}{*}{ Growth } & 0.000 & $-0.005 * * *$ & $0.003 * *$ & 0.000 & $-0.006 * * *$ & $0.003 * *$ \\
\hline & $(0.23)$ & $(-3.75)$ & $(2.52)$ & $(0.14)$ & $(-4.22)$ & (2.29) \\
\hline \multirow[t]{2}{*}{ CrossList } & -0.003 & $-0.023 * * *$ & -0.006 & -0.001 & $-0.016 * *$ & -0.002 \\
\hline & $(-1.09)$ & $(-3.21)$ & $(-0.92)$ & $(-0.37)$ & $(-2.08)$ & $(-0.23)$ \\
\hline \multirow[t]{2}{*}{ GDP } & $-0.682 * * *$ & -0.139 & $-0.240^{*}$ & $-1.143 * * *$ & -0.262 & $-0.365^{*}$ \\
\hline & $(-3.59)$ & $(-1.03)$ & $(-1.85)$ & $(-3.68)$ & $(-1.22)$ & $(-1.75)$ \\
\hline \multirow[t]{2}{*}{ SOE } & & & & -0.001 & $-0.013 * * *$ & $-0.005^{*}$ \\
\hline & & & & $(-0.51)$ & $(-3.90)$ & $(-1.67)$ \\
\hline \multirow[t]{2}{*}{ Big4 } & & & & $-0.004 *$ & $-0.019 * * *$ & $-0.013 *$ \\
\hline & & & & $(-1.77)$ & $(-2.99)$ & $(-1.82)$ \\
\hline \multirow[t]{2}{*}{ Gender } & & & & $0.004 * * *$ & 0.002 & -0.001 \\
\hline & & & & $(2.72)$ & (1.02) & $(-0.39)$ \\
\hline \multirow[t]{2}{*}{ ln_age } & & & & $-0.013 * * *$ & 0.001 & -0.004 \\
\hline & & & & $(-3.48)$ & $(0.21)$ & $(-1.01)$ \\
\hline \multirow[t]{2}{*}{ Isduality } & & & & -0.001 & -0.006 & 0.006 \\
\hline & & & & $(-0.15)$ & $(-1.18)$ & $(1.49)$ \\
\hline _cons & $0.321 * * *$ & $0.363 * * *$ & $-0.265^{* * *}$ & $0.633 * * *$ & $0.407 * * *$ & -0.192 \\
\hline
\end{tabular}




\begin{tabular}{lcccccc} 
& $(3.19)$ & $(4.66)$ & $(-3.56)$ & $(3.61)$ & $(3.23)$ & $(-1.58)$ \\
\hline $\mathrm{N}$ & 21749 & 21749 & 21749 & 21749 & 21749 & 21749 \\
$\begin{array}{l}\text { Industry } \\
\begin{array}{l}\text { Fixed } \\
\text { effect }\end{array}\end{array}$ & Yes & Yes & Yes & Yes & Yes & Yes \\
$\begin{array}{l}\text { Year } \\
\text { Fixed }\end{array}$ & Yes & Yes & Yes & Yes & Yes & Yes \\
Effect & & & & & & \\
r2_a & 0.825 & 0.286 & 0.376 & 0.825 & 0.289 & \\
\hline
\end{tabular}

Table 4 reports the results adding the variables: whether it is state-owned, whether it is audited by the Big Four audit firms, gender of the company's senior executives, age of the senior executives, and duality of senior executives.t statistics in parentheses

$* \mathrm{p}<0.1, * * \mathrm{p}<0.05, * * * \mathrm{p}<0.01 \mathrm{f}$ senior executives.

\subsection{Further analysis}

To explore in-depth whether the impact of EPU on the leverage ratio will be different due to the nature of the company, we classified the samples according to the scale of whether they are state-owned enterprises and whether the Big Four audit firms audit them. In Table 4, the first column shows the results of SOEs, the second column shows the results of the companies audited by the Big Four, the third column shows the results of NSOEs, and the fourth column shows the results of companies not audited by Big Four. We found that EPU will impact the leverage only when the company is an NSOE and is not audited by the Big Four audit firms since the negative results only appear in the third and fourth columns.

This distinction may be due to the different nature of Chinese companies. In relation to this finding, one of the studies [19] on Chinese firms showed that SOEs take a longer time adjusting to their leverage policy than NSOEs, which may be a possible explanation. In addition, according to the result of an analysis run by Deventer and Malatesta [24] conducting a large-sample cross-sectional comparison of SOEs and NSOEs, SOEs are more highly leveraged than NOSEs, which may make them hard to monitor

Table 5. Further analysis of classified, original samples. Categories (ordered from columns 1-4): State-owned enterprises, firms audited by the Big Four, non-stateowned enterprises, firms not audited by the Big Four.

$\begin{array}{llll}(1) & (2) & (3) & (4) \\ \text { SOE } & \text { Big4 } & \text { NON } & \text { NON }\end{array}$

\begin{tabular}{|c|c|c|c|c|}
\hline & & & SOE & Big4 \\
\hline \multirow[t]{3}{*}{ EPU } & -0.016 & 0.028 & - & - \\
\hline & & & $0.129 * * *$ & $0.088 * * *$ \\
\hline & $(-0.52)$ & $(0.57)$ & $(-4.07)$ & $(-3.60)$ \\
\hline \multirow[t]{2}{*}{ Lev } & $\begin{array}{l}0.884 * \\
* *\end{array}$ & $0.873 * * *$ & $0.841 * * *$ & $0.859 * * *$ \\
\hline & $\begin{array}{l}(138.4 \\
6)\end{array}$ & (44.54) & (131.55) & (183.70) \\
\hline \multirow[t]{2}{*}{ Size } & $\begin{array}{l}0.007 * \\
* *\end{array}$ & $0.006^{* * *}$ & $0.005^{* * *}$ & $0.006^{* * *}$ \\
\hline & $(8.48)$ & $(2.94)$ & (4.69) & $(8.44)$ \\
\hline \multirow[t]{3}{*}{ Age } & - & -0.001 & - & - \\
\hline & $\begin{array}{l}0.007 * \\
*\end{array}$ & & $0.009 * * *$ & $0.010^{* * *}$ \\
\hline & $(-2.41)$ & $(-0.12)$ & $(-3.48)$ & $(-5.18)$ \\
\hline \multirow[t]{3}{*}{ Frs } & - & - & 0.004 & -0.001 \\
\hline & $0.011^{*}$ & $0.041 * * *$ & & \\
\hline & $(-1.89)$ & $(-2.91)$ & $(0.73)$ & $(-0.18)$ \\
\hline \multirow[t]{2}{*}{ Growth } & -0.000 & 0.001 & 0.000 & 0.000 \\
\hline & $(-0.17)$ & $(0.19)$ & $(0.15)$ & $(0.18)$ \\
\hline \multirow[t]{3}{*}{ CrossListt } & - & 0.002 & 0.003 & -0.003 \\
\hline & $\begin{array}{l}0.005^{*} \\
*\end{array}$ & & & \\
\hline & $(-2.12)$ & $(0.43)$ & $(0.40)$ & $(-0.99)$ \\
\hline \multirow[t]{3}{*}{ GDP } & -0.084 & 0.478 & - & - \\
\hline & & & $1.909 * * *$ & $1.219 * * *$ \\
\hline & $(-0.21)$ & $(0.72)$ & $(-4.42)$ & $(-3.70)$ \\
\hline \multirow[t]{2}{*}{ _cons } & 0.017 & -0.306 & $0.999 * * *$ & $0.635^{* * * *}$ \\
\hline & $(0.07)$ & $(-0.82)$ & $(4.14)$ & $(3.45)$ \\
\hline $\mathrm{N}$ & 10083 & 1352 & 11666 & 20397 \\
\hline $\begin{array}{l}\text { Industry } \\
\text { Fixed effect }\end{array}$ & Yes & Yes & Yes & Yes \\
\hline
\end{tabular}




\begin{tabular}{lcccc}
$\begin{array}{l}\text { Year Fixed } \\
\text { Effect }\end{array}$ & Yes & Yes & Yes & Yes \\
r2_a $\quad 0.838$ & 0.867 & 0.798 & 0.822 \\
\hline t statistics in parentheses & & \\
$* \mathrm{p}<0.1, * * \mathrm{p}<0.05, * * * \mathrm{p}<0.01$ &
\end{tabular}

\section{CONCLUSIONS and DISCUSSIONS}

Firstly, we have conducted empirical analysis investigating whether economic policy uncertainty impacts corporate leverage, using Baker's [10] EPU index and data of all listed companies on the Shanghai and Shenzhen stock exchanges from 2007 to 2018 extracted from the CSMAR platform. The results show a significant negative relationship between EPU and leverage which also holds after robustness tests, indicating a reduction of leverage when EPU arises.

Secondly, when estimating the impact of EPU, we distinguished short-term leverage and long-term leverage, hence found that EPU has a more significant impact on the short-term leverage ratio. It indicates that firms tend to reduce short-term debts before long-term debts when economic policy uncertainty arises. This finding can implicitly prove the existing studies accentuating the higher liquidity risk of short-term liabilities and relate to studies suggesting that firms should closely and carefully monitor short-term debts.

Finally, when doing further analysis using a classified form of original samples, we noted that differences in property rights attributes and audit quality are possible factors influencing the effect of EPU on leverage. Since in results using classified data, only companies that are not audited by the Big Four audit firms and non-state-owned companies show a significantly negative relationship, which indicates a reduction of leverage when EPU increases. We related that finding to the nature of SOEs and Chinese firms in which SOE firms hold larger debt and take longer to change their leverage. However, reasons why audit quality will influence the impact of EPU on leverage still remain an unclear direction for us.

\section{REFERENCES}

[1] Ilyukhin, E. (2015). The Impact of Financial Leverage on Firm performance: Evidence from Russia. Journal of Corporate Finance Research Corporate Finance, CyberLeninka; Federal State Autonomous Educational Institution of Higher Education National Research University Higher School of Economics, 2(34), 24-36.

[2] Gahlon, J. M. (1981). Operating leverage as a determinant of systematic risk. Journal of Business Research, (9)3, 297-308. DOI: https://doi.org/10.1016/0148-2963(81)90023-0
[3] Lev, B. (1974). On the Association between Operating Leverage and Risk. Journal of Financial and Quantitative Analysis, 627-641. DOI: https://doi.org/10.2307/2329764

[4] Barclay, M. J., Smith, C. W., Watts, R. L. (1995). The Determinants of Corporate Leverage and Dividend Policies. Journal of Financial Education, 23, 1-15. DOI: https://doi.org/10.1111/j.17456622.1995.tb00259.x

[5] Geanakoplos, J. (2009). The Leverage Cycle. Cowles Foundation Discussion Paper. No. 1715. p.2, 16-21. p.3, 13-18. DOI: http://dx.doi.org/10.2139/ssrn.1441943

[6] Glen, J. D. \& Pinto, B. (1994). Debt Or Equity? How Firms in Developing Countries Choose. p.12, 10-18. DOI: https://doi.org/10.1596/0-8213-2974$\mathrm{X}$

[7] Segal, T. (2020). China A-Shares Definition. Retrieved May 27, 2021, from https://www.investopedia.com/terms/a/a-shares.asp

[8] Rodrik, D. (1991). Policy Uncertainty and Private investment. Journal of Development Economics. 36(2), Pages 229-242. DOI: https://doi.org/10.1016/0304-3878(91)90034-S

[9] Dadush, U., Dasgupta, D., Ratha, D. (2000). The Role of Short-Term Debt in Recent Crises. Finance and Development. 37(4). p.7, 23-27.

[10] Baker, S. R., Bloom, N., Davis, S. J. (2016). Measuring Economic Policy Uncertainty. The Quarterly Journal of Economics, 131(4), 15931636. DOI: https://doi.org/10.1093/qje/qjw024

[11] Zhang, G., Han, J., Pan, Z., \& Huang, H. (2015). Economic Policy Uncertainty and Capital Structure Choice: Evidence from China. Economic Systems

$39(3)$

439-457.

DOI:

https://doi.org/10.1016/j.ecosys.2015.06.003

[12] Trung, T. Q. (2019). Economic policy uncertainty and corporate risk-taking: International evidence. Journal of Multinational Financial Management, $52(2)$.

DOI: https://doi.org/10.1016/j.mulfin.2019.100605

[13] Qiu, M. \& Li, X. (2018). Capital Structure and Economic Policy Uncertainty: US versus German Firms. Working Paper. Massey University. Retrieved from https://www.efmaefm.org/0EFMAMEETINGS/EF MA\%20ANNUAL\%20MEETINGS/2017Athens/papers/EFMA2017_0594_fullpaper.pdf

[14] Makololo, P. \& Seetharam, Y. (2020). The Effect of Economic Policy Uncertainty and Herding on 
Leverage: An Examination of the BRICS Countries. Cogent Economics \& Finance, 8(1). DOI: https://doi.org/10.1080/23322039.2020.1821482

[15] Pan, Z., Liu, L. (2018). Forecasting stock return volatility: A comparison between the roles of shortterm and long-term leverage effects. Physica A: Statistical Mechanics and its Applications, 492(15), 168-180.

DOI:

https://doi.org/10.1016/j.physa.2017.09.030

[16] Engle, R. F., Ghysels, E., Sohn, B. (2013). Stock market volatility and macroeconomic fundamentals. The Review of Economics and Statistics, 95(3), 776-797.

DOI: https://doi.org/10.1162/REST_a_00300

[17] Dehuan, J., Jin, Z. (2008). Firm Performance and Stock Returns: An Empirical Study of the Top Performing Stocks Listed on Shanghai Stock Exchange. Academy of Accounting and Financial Studies Journal, 12(1), 79-85.

[18] Alkhatib, K. (2012). The Determinants of Leverage of Listed Companies. International Journal of Business and Social Science, 3(2), 78-83.

[19] Mirza, S. S., Ajid ur Rehman, Zhang, Z. (2016). Adjustment Behavior of Leverage in Chinese Firms: An Empirical Analyses of Overall Firms, State-owned and Non-state-owned Enterprises. Asian Academy of Management Journal of Accounting and Finance, 12(2), 95-126. p.95-120. DOI: https://doi.org/10.21315/aamjaf2016.12.2.5

[20] Yang, C., Chiang, M., Chen, C. (2018). Financial Leverage and Competitive Strategy of Cross-listing Firms. Australian Journal of Management, Vol. 44(2), 306-324. DOI: https://doi.org/10.1177\%2F0312896218792967

[21] Augustin, P., Feng, J., Sarkissian, S., Schill, M. J. (2019). Cross-Listings and the Dynamics between Credit and Equity Returns. Review of Financial Studies, 33(1), 112-154. DOI: https://doi.org/10.1093/rfs/hhz052

[22] Diamond, D. W., He, Z. (2014). A Theory of Debt Maturity: The Long and Short of Debt Overhang. The Journal of Finance, Vol. LXIX(2), 719-762. DOI: https://doi.org/10.1111/jofi.12118

[23] Retrieved $4^{\text {th }} \quad$ May, 2021, from http://www.policyuncertainty.com/china_epu. html

[24] DeWenter, K. L and Malatesta, P. H. (2001). State Owned and Privately Owned Firms: An Empirical Analysis of Profitability, Leverage, and Labor Intensity. American Economic Review; MAR 2001,
91(1), 320-334. DOI:

https://doi.org/10.1257/aer.91.1.320 